\title{
A matter of degrees: The role of education in the professionalisation journey of social work in New Zealand
}

\section{Liz Beddoe}

Liz Beddoe is an Associate Professor at the School of Counselling, Human Services and Social Work, The University of Auckland.

\begin{abstract}
Social work in Aotearoa New Zealand (ANZ) is a contested profession on a journey of professionalisation in an era where contradictory forces impact on its position and strength. Social work education reflects these tensions, being influenced by economic and political forces. The delineation of a benchmark qualification for entry is a core feature of professional status and so the inception of professional registration has impacted on social work education in ANZ as it has elsewhere. The aim of this paper is to explore dimensions of the history of social work education in ANZ, the impact of the Social Workers Registration Act (2003) (SWRA) and to examine some current constraints and consider the challenges professional education faces in the next 50 years. It is argued that social work education has been, is and will remain a site of struggle.
\end{abstract}

\section{Introduction}

Social work in the 21st century occupies a narrow and risky perch within a rolled back welfare state. In Aotearoa New Zealand (ANZ), social work remains a contested profession on a journey of professionalisation in an era where contradictory forces impact on its position and strength (Harington \& Beddoe, 2013). In ANZ it can be argued that the impetus toward regulation has strengthened the case for social work education, while weakening its independence and diversity. Van Heugten (2011, p. 175) questioned whether the onset of registration would lead to '.... an emphasis on competency, skills, essentialist ideology, and knowledge for practice in agencies' that might '...squeeze critical social science and social scientists out of the social work academy?' This is an interesting question to ponder as the neoliberal project of managerialism has tended to value the instrumental aspects of education over the radical and transformative. And in some countries, as will be shown further on in this paper, governments can and do influence the content of professional education. While theory and evidence are cornerstones of professional education, which theories and what evidence may be contested, and even the need to educate beyond basic competence and common sense may be challenged by ambivalence within and outside the profession (Green, 2006). As Heite (2012, n.p.) notes, in social work the 'boundaries between profession and non-profession, like those between science and non-science, are historically specific, changeable, inconsistent and fought over', demonstrating uncertainty about our place. Heite 
invokes Gieryn's work on the boundaries between professions and non-professions, where social work can appear '.... at once theoretical and empirical, pure and applied, objective and subjective, exact and estimative, democratic (open for all to confirm) and elitist (experts alone confirm), limitless and limited (to certain domains of knowledge)' (Gieryn, 1983, p. 792). Thus, social work education tussles with ambiguity.

Education is at the heart of the professionalisation of social work. Olgiati notes that in all the professions one:

...common pattern whose existence is shared by all specialists (and thereby distinguishing professions from other occupations) is the connection of profession with a particular educational training and the practice of a particular type of knowledge, basically academic knowledge (Olgiati, 2006, pp. 540-541).

Social workers have often rejected an outright knowledge claim as elitist, while at the same time believing in a unique approach and wishing to have some ability to protect vulnerable client groups from the impact of poor practice. Qualifying education for social work is the foundation on which its professional claim is grounded. Additional significant dimensions of social work's professional journey - status, relationships with other professions, confidence in the knowledge base and so forth - have been discussed elsewhere, drawing on the author's doctoral research (Beddoe, 2011, 2013a, 2013b, 2013c).

Social work (and its education) reflects wider policy tensions as it works to stake its claim in the complex and crowded territories of social welfare, education, health and justice and is influenced by economic and political forces. Registration is primarily sought in order to achieve professional legitimacy (Beddoe, 2013a, 2013c; O'Brien, 2005), but along the way may challenge some core beliefs about our being agents of change. While much of the focus has been on '... achieving professional legitimacy'( O'Brien, 2005, p. 17), O'Brien (2005) and Harington and Beddoe (2013) argue that professionalisation need not automatically mean a diminished role in public advocacy, rather that greater legitimacy can be applied to building a strong public voice alongside groups disadvantaged by structural inequality and poverty.

As noted elsewhere (Beddoe, 2007), registration in ANZ was a political choice in the early years of this century. In order for the state to be seen to be responding to child abuse tragedies, the New Zealand Government allowed for limited registration, with the Social Workers Registration Board (SWRB) empowered to set a qualification-based benchmark for entry. This followed a period of intense political criticism of social work. Internationally, most inquiries into practice failures inevitably address the role of social work education and training (Wilson \& Campbell, 2012). New Zealand thus followed a pattern found elsewhere - in the United Kingdom, for example, where registration occurred at about the same time and in a similar climate (McLaughlin, 2007). As the environment becomes more litigious, and professions are held to greater account, the validation and accreditation of professional qualifying programmes becomes more complex and control of social work education may be subject to greater scrutiny (van Heugten, 2011). Political commitment to social work however remains ambivalent, as evidenced in the failure of the present Government to seize the opportunity to make registration mandatory despite significant critique of the current confusing 'voluntary' system. 
With reference to the political environment, this paper will explore the series of major incremental changes which have occurred for social work qualifying programmes - moving from a Diploma in Social Work (established largely by consensus in the 1980s) to a three- year bachelor's degree required for new registrations from 2006. Only a little more than one decade from that change, the SWRB has set a target date of 2017 for all BSW degrees to be four years in duration. A period of consultation amongst sector stakeholders resulted in a discussion paper that recommended the benchmark become a four-year degree (or two-year masters) (SWRB, 2012). Arguments in favour for a four-year degree as the standard undergraduate first professional qualification included the following: the current mix of qualifications is confusing, giving an impression of different tiers of qualification; that a longer degree made greater academic rigour possible; that students would be better prepared to meet industry needs; that research mindedness and preparation for postgraduate study would be improved; and, finally, an improved proportion of classroom time in relation to time taken up by field placements. In addition, it was noted that it is difficult to get employment overseas with a three-year degree and that ANZ graduates needed to undertake further study in order to practise in Australia.

Arguments against mainly coalesced around the resources needed to fund a longer programme, including concerns over increased costs for students, costs for employers who support staff to gain professional qualifications and the resources to staff three year programmes in smaller, regional tertiary institutions. The official decision requiring the benchmark qualification to be a four-year degree was announced on 26th November 2012 notifying changes to the programme recognition standards. The SWRB advises that they expect all providers to apply for recognition of a four-year degree.

\section{A brief history of social work education in Aotearoa New Zealand}

While the aim of this paper is to discuss recent developments in social work education, it is necessary to understand a little of our history. For a comprehensive account of ANZ social work education, see Nash (1998). The gendered origins of social work in ANZ in child welfare in education (Nash, 2009) and in handmaiden roles in health as an expansion of nursing (Mattinson, 1951; Spensley, 1953; Beddoe \& Deeney, 2012) initially favoured a perspective in which personal attributes were of greatest significance building on prior experience in related professions of teaching and nursing, although by the 1960s the professional association had aspirations for the intensification of social work education in universities (Ritchie, 1967). Interest grew and various reviews sought to examine the profile of the profession. Daniels states that only about 14\% of social workers held a qualification in 1969 (Daniels, 1973, p. 47).

In this special issue which celebrates the 50th anniversary of (Aotearoa) New Zealand Association of Social Workers (ANZASW) it is notable that social work education was a central issue from the very early years. Ritchie (1967) discussed the challenges facing NZASW, at that time a very young professional association, as it struggled to develop a professional foundation for social work. Ritchie emphasised that a university qualification in itself does not justify a claim for professional status. For Ritchie membership of a profession requires 'an agreed system of ethics', a 'sense of vocation' and a lifetime commitment to the aims of the profession (Ritchie, 1967, p. 5). Ritchie also acknowledges the importance of the university in the socialisation of new practitioners to the profession: the processes of 'un-learning', experiencing new learning and the construction of a new professional identity (1967, p. 25). 
Ritchie's prescription for a strong profession was for social workers to complete a four-year undergraduate degree, in social sciences, followed by a two-year postgraduate social work programme, then an internship year $(1967$, p. 11). To some extent these components have all operated as models.

Social work education was launched in 1950 at what is now Victoria University of Wellington, and Nash (2001) notes that this programme was to be highly influential in shaping social work education for many decades, graduates going on to be included in the group that wrote the minimum standards in 1975. By 1981 a large study of social work in ANZ reported that only $12 \%$ of social workers held a social work qualification (Rochford \& Robb, 1981). There was a steady growth of options over the period 1973-1986 as new degree programmes flourished at Massey (1976) and Canterbury (1980) universities, and a new diploma was established at the Auckland College of Education (1982). The demand for social work education increased and debates ensued about the location and accessibility of opportunities. Nash and Munford (2001) outline the political machinations that followed as various quangos waded in to a murky territory. As a compromise in the highly contentious seesaw of quantity versus quality, the NZ Council for Education and Training in the Social Services developed requirements for the famous Level A and Level B certificates, which led to a proliferation of programmes with low entry requirements. This body was replaced by another body, Te Kaiawhina Ahumahi Industry Training Organisation (TKA), which set about expanding further the base of lower-level qualifications, including allowing for 'work-based training' for social workers where practitioners were not taught but assessed (often by an army of minimally qualified private consultants) until they could gain 'unit standards'. TKA was a microcosm of the tensions and conflicts within social work in ANZ at the time. Among its stakeholder nominees were experienced and qualified social workers who struggled to ensure that the standards proposed for social work education bore some resemblance to the international profession's values and aims, and ensured at least a minimal level of 'fit for purpose' for the jobs graduates would enter.

Little is known about the current workforce, as research on professional issues is poorly funded and supported in ANZ, in comparison to other professions. An examination of the 2001 New Zealand census data found only 19\% of those who self-identified in the social work category also reported having qualifications, while 53\% held some post-school qualifications. Harington and Crothers point out:

...these data do not elaborate on the nature of the educational qualifications that have been achieved ... [they] may not be in social work, and there could have been a great deal of water under the learning curve bridges masked in these figures (Harington \& Crothers, 2005, p 8).

Data from the 2006 and 2013 censuses have not been analysed. The SWRB reports that at 31st December 2013 there were 4,388 registered social workers, with 50 in the process of completing their social work qualification. We currently have recognised programme at 18 institutions: universities (5), in wananga (2), polytechnics (9) and one private training institute.

\section{Education: At the heart of the debates on registration}

Registration inevitably brings up debates about the purpose of greater regulation. These debates essentially form around two main strands of opposing argument: one, that regis- 
tration is essential to protect the public and ensure high standards of practice and two, that professional regulation is grounded in elitism and occupational closure (Beddoe, 2013c). Inevitably education sits at the heart of these debates, and whether there should be requirements for formal qualifications for social work had been discussed within ANZ for several decades, and was the cause of considerable tension within the profession in the late 1980s and early 1990s (Beddoe \& Randal, 1994). Add to this the growing critique of social work from Tangata Whenua, within and outside the profession and the fault lines come together around the often antagonistic discourses of anti-racism and nascent professionalism. Prior to the passing of the SWRA (2003), social work still had low levels of formal professional education and for many decades there was confusion about the standards for pre-service education (Randal, 1997). Despite the aspirations of the 1960s (and university preparation having been available since 1949), by the 1990s entrants to the profession still possessed anything ranging from no qualification, a certificate, a degree or a postgraduate qualification in social work (Nash, 1997; Nash \& Munford, 2001). Social work education was the subject of much debate in ANZ (Beddoe \& Randal, 1994) and proponents of professionalisation have long argued that formal education is the major boundary setter between voluntary welfare work and 'professional' social work.

By the late 1990s the ANZASW had become a strong supporter of registration (ANZASW, 2000). The tide had turned, and with the development of albeit limited registration ANZ social work was on the political agenda. Ministerial sponsorship of the development of registration legislation was a direct outcome of a decade of criticism of public sector social work, which had been explored critically in the Brown report. This major review of the Department of Child, Youth and Family Services called for registration of social workers and an improvement in qualifications (Brown, 2000). In 2000 the Ministry of Social Policy distributed a discussion paper, 'Registration for Social Workers', as part of the consultation on establishing a formal system for the registration of social workers, and this was generally supported by the main political parties (Ministry of Social Policy, 2000). A summary of the findings of the consultation reported that all respondents were in favour of registration for social workers (Ministry of Social Policy, 2001).

As noted in Beddoe and Duke (2009), the stated reasons outlined in support of registration reflected the political climate about child and family social work:

... that registration would: set and maintain high levels of professionalism and minimum standards of practice; result in increased safety and protection for all stakeholders (including clients and social workers); and provide a formal mechanism for accountability for the social work profession (Ministry of Social Policy, 2001).

The summary of the policy paper demonstrates that relatively few submissions expressed concerns about the principle of registration, and those noted reservations concerned potential exclusions of competent practitioners who were currently working without qualifications, youth and community workers and Maori social workers. These were important concerns and expected to be addressed by ensuring regional access to qualifying programmes and support, especially for the NGO sector. The Ministry consultation also found that $93 \%$ of submissions received supported the role of a regulatory board in setting and enforcing codes of conduct and standards of practice (p.6). The development of a register of all social workers and a mechanism that could investigate complaints, conduct disciplinary hearings and impose sanctions - including re-training and deregistration - was supported by all respondents. 
The SWRA (2003) was duly passed and came into effect in October 2004. Before social workers could be recognised, the SWRA required the SWRB to set a benchmark qualification for registration. The SWRB was guided by the finding in the consultation process that $91 \%$ of respondents thought the board should set the entry criteria (Ministry of Social Policy, 2001, p. 7). However, there had been some debate about whether setting educational standards as entry criteria should be a function of the registration board or of a separate education council established under the same Act (Ministry of Social Policy, 2001, p. 7). This latter ambivalence about the role of the board was to cause conflict in due course.

The SWRB (convened on 5th November 2003) was obliged to have set all the requirements for registration in time to be able to accept applications for registration from 1 October 2004. The Education and Practice Standards Committee was tasked with undertaking a consultation process and developing a schedule of current and historical qualifications in social work. A subcommittee undertook a consultation process that was by necessity brief, and as a consequence subject to criticism by a sector struggling with the impact of change. It needs to be noted that the rapidity of decision making was mandated by timeframes within the legislation itself (Beddoe, 2007; Beddoe \& Duke, 2009) and not by actions of the board.

\section{Discussion: Who drives social work education in 2014?}

So, five decades after the NZASW began to advocate for educational benchmarks and professional standards, where did we get to? While there is a consensus that education should turn out graduates with a set of predictable knowledge(s), skills, values and dispositions (Nash, 2001, p. 29), just what that knowledge set is, who determines its features, which dispositions are the 'right' ones, and how all this is transmitted remains a site of struggle and debate (Nash \& Munford, 2001). This struggle has been a constant in social work in many countries. At the time of writing, social work education in the United Kingdom is again in the spotlight. The Narey report on education for children's social work, recently released in the United Kingdom, rejects the International Definition of Social Work on the basis that the current Secretary of State for Education, if he knew about it probably would not think it 'adequate' presumably because it emphasises a commitment to social justice rather than bureaucratic focus (Narey, 2014, p. 13). Narey, a former public servant and now 'advisor to government', favours a separation of education for adult and children's social work, but cites no research in challenging the generic degree, other than anecdote. It is his contention that much content about the elderly is of limited use to social work graduates. For example, he states, '...the study of human growth and development across the whole life cycle, currently taught at many universities, could be more usefully replaced by a more concentrated study of child development' (Narey, 2014, p. 38), thus seeming to marginalise the needs and roles of parents and grandparents as if children were raised in a vacuum.

While it is likely that social work education will continue to be a site of contestation there is a broad consensus between the stakeholders about the content and form of social work degrees. To ensure that there are criteria for the review of programmes for purposes of recognition the SWRB sets out its expectations (SWRB, 2013). These are generally not very prescriptive, compared to other jurisdictions, with the exception relating to the requirements for field placements. Table one sets out the SWRB Expectations re Core Competencies and Curriculum. On examination they align with the ANZASW Practice Standards and reflect fairly universal expectations for social work. 
Table one. SWRB expectations re core competencies and curriculum.

Core Competencies

Competence to practise social work with Maori

Competence to practice social work with different ethnic and cultural groups in Aotearoa New Zealand

Adherence to professional social work ethics

Competence to promote the principles of human rights and social justice

Competence to promote social change.

Competence to promote empowerment and liberation of people

Competence to utilise social work practice approaches

Competence to utilise theories of human behaviour and social systems

Competence to promote problem solving in human relationships

Competence to ensure systems of accountability are in place for their work.

\section{Curriculum}

The curriculum is strongly focused on social work practice, located within the New Zealand and international contexts, cognisant of the imperative of Te Tiriti o Waitangi Articles in social service provision.

The curriculum reflects the principles of social justice and ethical conduct.

The curriculum is designed to ensure graduates will be competent to practise social work with Maori.

The curriculum is designed to ensure graduates will be competent to practise social work with different ethnic and cultural groups in New Zealand.

The curriculum includes material pertaining to a comprehensive array of socially marginalised and vulnerable groups.

The curriculum includes integration of relevant social work theory, research and practice for achieving the core knowledge, processes, values and skills for social work practice in Aotearoa New Zealand and internationally.

The curriculum is designed to ensure graduates will be competent to practise with individuals, families, groups and / or communities in any given context.

The curriculum provides for the application of theory and critique of research within the development and advancement of practice skills (via detailed practicum requirements).

The programme has social work skills teaching across the curriculum that addresses interpersonal skills, reflective practice, supervision and risk assessment in preparation for placement.

The programme delivery, especially at undergraduate level, will include multidisciplinary input, particularly drawing from the social science disciplines of sociology, social policy, cultural studies, psychology and law.

Source: SWRB (2013). The process for recognition and re-recognition of social work qualifications in New Zealand.

Despite there seeming to be a broad consensus amongst stakeholders about social work education, delegates to the 2013 SWRB-hosted conference 'Protecting the Public-Enhancing the Profession' were surprised when in her role as opening speaker to welcome delegates, 
Minister of Social Development Paula Bennett launched a vague attack on social work, seemingly fuelled by anecdote:

I think there has been questions repeatedly raised for me (sic) both within the Child, Youth and Family organisation but wider than that in all of those other organisations that are working in it, not just about the capability of those who are within the sector now but the capability of those who are coming out of the universities and tertiary institutions (Bennett - transcribed speech, 11 November, 2014).

Thus it behoves us to avoid becoming too complacent about the extent to which we are self-governing. The SWRB does report to Parliament through the Minister of Social Development and broad agreements between governments, professional bodies and employers can change. While transcribed speech is notoriously imprecise, it seems that the minister has talked to some people inside and outside CYF, though the latter point is unclear, and heard concerns about the quality of social work education. From these conversations she surmises that social work graduates are challenged by home visits, and thus questions the degree:

How much time is spent dealing with how you get through the door of a family or a child's home that you have to be at but they completely do not want you there? How much time is spent on the actual capability and skills that are needed to be truly effective in the job? Now some of that you can only learn hands-on and there and there are no comparison, yeah? But police do six months and then two years on the job training - yeah? ... but still, that extra two years training ... in my mind needs a damn good look at (sic) (Bennett - transcribed speech, 11 November, 2014).

\section{Current challenges}

There are some ongoing wicked problems in social work education. There has been no increase in the core funding for social work education despite advocacy. Social work education is thus funded at the humanities rate, which is inadequate to cover the real costs of intensive skills teaching and field education. Employers still anecdotally report some shortages of suitable social workers and we do have an aging workforce, and, despite having so many programmes, it seems that some agencies still employ unqualified workers. The proliferation of programmes and increases in student numbers since a low point in 2006 means that there is continuing pressure on placements. Proving that some of the problems of social work education are indeed intransigent, Robb wrote in 1959 that because of a shortage of suitable supervisors 'the number of students has to be strictly limited' at the School of Social Science at Victoria University of Wellington (1959, p. 13). While schools of social work are infinitely creative in finding placements for students, this is stressful and resource intensive. The problem of quality placement shortages is universal, and recent reports in England have also noted that ways must be found to ensure quality placements and supervision (Croisdale-Appleby, 2014; Narey, 2014). While this pressure is a preoccupation, it is a challenge that all schools struggle with to avoid a focus on numbers, not quality.

One of the foundational purposes of degree-level education is to prepare students for postgraduate study and research alongside professional preparation where relevant; indeed this is enforced within the education system (Tertiary Education Commission, nd). Orme and Powell (2008) note that research has not been a high priority in education or practice until the 'modernisation' of education, health and social work systems with the concomitant shift to evidence-based practice. In the age of evidence-led policy and practice, local scholarship 
is relatively weak and social work does run the risk of being outrun by other professions where postgraduate training and participation in research is much more prevalent.

The relative paucity of research on social work in ANZ has been in part a feature of traditional recruitment practices, where schools of social work have recruited practitioners, often on the strength of a master's degree, from whence they play catch-up, balancing teaching, service, family and PhD study if so motivated. Field education and skills teaching has often been the focus of entry to an academic career for practitioners. Orme and Powell (2008, p. 993) suggest this practice evolved in part to, ' ... defend the identity and interests of the profession' and deliver the practice curriculum, and in ANZ there have been insufficient PhD graduates to fill all positions. While little is known of the academic workforce, it is likely that this picture is changing - in the author's own school, of the social work qualified academics, 10 academics have $\mathrm{PhD}$, four are doctoral candidates and the others have master's degrees. In the new environment $\mathrm{PhD}$ enrolment is encouraged and supported, although part-time study is very challenging. In Australia, Agbim and Ozanne (2007, p. 79) reported growing support for improved research activity amongst Australian educators, whom they note 'spoke of a need for greater inclusion of research training in the ... curriculum and for educators themselves', requiring a culture change to reduce teaching loads and encourage ongoing research. Workloads and the development of scholarly cultures will remain a challenge for social work scholarship and research in ANZ (Beddoe, 2011) especially in the current climate of reducing government funding for tertiary education and social science research.

On the positive side, in spite of local and international fears that greater regulation of social work would lead to instrumental approaches to education, in ANZ the SWRB does not appear to wish to stifle education that is intellectually robust. Rather, the staffing policies suggest that the Board is keen to raise the research capability of social work graduates by raising the bar for academic staff as well and ensuring that policies are in place to support staff research activity. Table two sets out the SWRB policy requirements for staff teaching/ supervising in recognised programmes

Table two. SWRB policy requirements for staff teaching/supervising in recognised programmes.

SWRB Recognition - Resources required - Staff

Staff teaching in core social work theory, skills and practice components of the programme and co-ordinating the placement of students at each recognised site are fully registered social workers.

Staff teaching in the social work theory, skills and practice components of an undergraduate degree are master's qualified or have a plan in place to complete a master's qualification within 2 years of appointment.

Staff teaching in the social work theory, skills and practice components of a postgraduate degree have a research master's degree or are enrolled in a doctoral programme with a plan in place to complete the doctoral degree within 4 years.

Teaching in the programme is undertaken by staff who are active in research, scholarship and/or critical reflective practice in the field.

The minimum expectations of registration, qualifications and experience of supervisors/field educators, and the mechanisms in place for the training and support of field educators/supervisors are clearly articulated. 
The programme leader is a research active fully registered social worker.

The tertiary education has an institutional workload allocation policy in place.

There are sufficient staff resources to generate and support a research active social work staff group.

Source: SWRB (2013). The process for recognition and re- recognition of social work qualifications in New Zealand.

\section{Conclusion}

There is recognition that a better educated, research minded and critical workforce is important for effective practice. Croisdale-Appleby (2014, p. 81) writes;

In political and media discourse this suspicion of the social work profession adopting an analytical approach rather than a 'common sense approach' has served to minimise understanding and appreciation of the complexity of the problems tackled by social workers, and given the impression that there are quick and obvious answers to complex social problems.

Developing the scholarship of social work is the major challenge for social work education in the next 50 years and there is room for optimism, despite the occasional bursts of anti-intellectualism that has so often plagued social work. Croisdale-Appleby (2014) provides this reflective quote from Avis in making a case for critical, reflective education.

Experience is never innocent. A pedagogy that fails to interrogate experience ultimately delivers a conservative politics. Such pedagogy fails to examine the discursive production of experience. It refuses to explore the way we position ourselves in relation to experience or the investments that tie us to particular positions and identities (Avis, 1995, p. 182).

Challenges will continue to come from many directions to social work education. Within the profession it is imperative that we urgently advocate for funding for research in the following areas: empirical workforce research to ensure we have the baseline information to plan and develop our workforce and evaluation of social work education including the student experience. In addition we need to develop a profession-wide beginning practitioner development and supervision programme to help reduce wasteful attrition in the workforce. It is time for the professional bodies and major employers to step up and invest in social work education and research in order to build the skills and knowledge base needed to meet future challenges. We have established a baseline qualification but this alone is insufficient to build the profession we aspire to be.

Note: I wrote this paper not as a dispassionate student of the history of the profession, but as someone who was an active participant in many of the bodies which have influenced our journey since the late 1980s. These experiences will undoubtedly have influenced my emphasis of some issues above others. It is my hope that other accounts of these last few decades in social work will be written.

\section{References}

Aotearoa New Zealand Association of Social Workers. (2000). Position paper on the statutory registration of social workers. Dunedin, New Zealand: ANZASW. 
Avis, J. (1995). The validation of learner experience: A conservative practice? Studies in the Education of Adults, 27(2), 173-186.

Beddoe, L. (2007). Change, complexity and challenge in social work education in Aotearoa New Zealand. Australian Social Work, 60(1), 46-55.

Beddoe, L. (2011). Investing in the future: Social workers talk about research. British Journal of Social Work, 41(3), 557-575.

Beddoe, L. (2013a). Continuing education, registration and professional identity in New Zealand social work. International Social Work. doi:10.1177/0020872812473139.

Beddoe, L. (2013b). A 'profession of faith' or a profession: Social work, knowledge and professional capital. New Zealand Sociology, 28(2), 44-63.

Beddoe, L. (2013c). Health social work: Professional identity and knowledge. Qualitative Social Work, 12(1), $24-40$.

Beddoe, L., \& Deeney, C. (2012). Discovering health social work in New Zealand in its published work: Implications for the profession. Aotearoa New Zealand Social Work, 24(1), 41-55.

Beddoe, L., \& Duke, J. (2009). Registration in New Zealand social work: The challenge of change. International Social Work, 52(6), 785-797.

Beddoe, L., \& Randal, H. (1994). NZASW and the professional response to a decade of challenge. In R. Munford \& M. Nash (Eds.), Social work in action (pp. 21-36). Palmerston North: Dunmore Press.

Brown, M. (2000). Care and protection is about adult behaviour: The Ministerial Review of the Department of Child, Youth and Family Services. Retrieved from https: / / www.msd.govt.nz/documents/about-msd-and-our-work/publications-resources / archive/2000-care-and-protection-is-about-adult-behaviour.pdf.

Croisdale-Appleby, D. (2014). Re-visioning social work education: An independent review. London.

Daniels, K. (1973). Social work education: A time of crisis. The New Zealand Social Worker: News and Opinions, 9(4), 43-55.

Gieryn, T.F. (1983) Boundary-work and the demarcation of science from non-science: Strains and interests in professional ideologies of scientists. American Sociological Review 48(6), 781-795.

Green, L. C. (2006). Pariah profession, debased discipline? An analysis of social work's low academic status and the possibilities for change. Social Work Education, 25(3), 245-264.

Harington, P. R., \& Beddoe, L. (2013). Civic practice: A new professional paradigm for social work. Journal of Social Work, 14(2), 147-164.

Harington, P.R., \& Crothers, C. (2005). The social work occupational category: The 2001 census data. Social Work Review, 18(4), 3-14.

Heite, C. (2012). Setting and crossing boundaries: Professionalization of social work and social work professionalism. Social Work and Society, 10(2), 1-14.

Mattinson, A. (1951). Social work in obstetrics. New Zealand Nursing Journal, 44(6), 171-173.

McLaughlin, K. (2007). Regulation and risk in social work: The General Social Care Council and the Social Care Register in context. British Journal of Social Work, 37(7), 1263-1277.

Ministry of Social Policy (2000). The registration of social workers: Discussion paper. Retrieved from http: / / www.msd.govt. nz/documents / about-msd-and-our-work/publications-resources/archive/2000-reg_socwork_discpaper.pdf.

Ministry of Social Policy (2001). Consultation report summary: The registration of social workers. Retrieved from https: / / www.msd.govt.nz/documents / about-msd-and-our-work/ publications-resources / archive/2001-reg_socwork_ consultationsummary.pdf.

Narey, M. (2014). Making the education of social workers consistently effective: Report of Sir Martin Narey's independent review of the education of children's social workers. London: Department of Education. Retrieved from https: / / www.gov.uk/government/publications / making-the-education-of-social-workers-consistently-effective.

Nash, M. (1997). Who drives social work education in New Zealand? Social Work Review, 9(4), 14-19.

Nash, M. (1998). People, policies and practice: Social work education in New Zealand 1949-1995. PhD thesis. Palmerston North: Massey University.

Nash, M. (2001). Educating social workers in Aotearoa New Zealand. In M. Connolly (Ed.), New Zealand social work: Contexts and practice (pp. 265-290). Auckland: Oxford University Press.

Nash, M. (2009). Histories of the social work profession. In M. Connolly \& L. Harms (Eds.), Social work: Contexts and practice (2nd ed., pp. 363-377). Melbourne: Oxford.

Nash, M., \& Munford, R. (2001). Unresolved struggles: Educating social workers in Aotearoa New Zealand. Social Work Education, 20(1), 21-34.

New Zealand Qualifications Authority. (undated). http:/ / www.nzqa.govt.nz/studying-in-new-zealand/nzqf/ understand-nz-quals / bachelor-s-degree/.

O'Brien, M. (2005). A just profession or just a profession? Social Work Review, 17(1), 13-22.

Olgiati, V. (2006). Shifting heuristics in the sociological approach to professional trustworthiness: The sociology of science. Current Sociology, 54(4), 533-547.

Randal, H. (1997). Competent practice and its regulation - Debating the issues around the registration and professionalisation of social work in New Zealand. Social Work Review, 9(1/2), 16-19.

Ritchie, J.E. (1967).The relation of the university to the profession of social work. The New Zealand Social Worker: News and Opinions, 3(2) pp. 3-13.

Robb, J. H. (1959). Similarities and differences in social work education as seen from New Zealand. International Social Work, 2(1), 11-14. 
Rochford, M. W., \& Robb, M. J. (1981). People in the social services. Wellington: New Zealand Social Work Training Council.

Shirley, I. (1997). Educating social workers in a changing cultural context: A New Zealand perspective. Social Work Review, 9(4), 12-13.

Social Workers Registration Act (2003). Wellington: New Zealand Government.

Social Workers Registration Board (2012). Social Work Programme Recognition Standards Review: Consultation Summary. Wellington: SWRB.

Social Workers Registration Board (2013). The process for recognition and re-recognition of social work qualifications in New Zealand. Retrieved from SWRB. http: / / www.swrb.govt.nz/policy.

Social Workers Registration Board (2014). Schedule of recognised New Zealand social work qualifications (January 2014). Wellington: SWRB Retrieved from http: / / www.swrb.govt.nz/new-applicants/recognised-qualifications.

Spensley, R. G. (1953). The nurse as a medical social worker. New Zealand Nursing Journal, 46(6), 177.

van Heugten, K. (2011). Registration and social work education: A golden opportunity or a Trojan horse? Journal of Social Work, 11(2), 174-190.

Wilson, G., \& Campbell, A. (2012). Developing social work education: Academic perspectives. British Journal of Social Work, 43(5), 1005-1023. 